\title{
High Efficiency Drug Repurposing Design for New Antifungal Agents
}

\author{
Jong H. Kim ${ }^{1, *}$, Kathleen L. Chan ${ }^{1}$, Luisa W. Cheng ${ }^{1}$, Lisa A. Tell ${ }^{2}$, Barbara A. Byrne ${ }^{3}$, \\ Kristin Clothier ${ }^{3,4}$ and Kirkwood M. Land ${ }^{5}$ \\ 1 Foodborne Toxin Detection and Prevention Research Unit, Western Regional Research Center, USDA-ARS, \\ 800 Buchanan St., Albany, CA 94710, USA; kathy.chan@ars.usda.gov (K.L.C.); \\ luisa.cheng@ars.usda.gov (L.W.C.) \\ 2 Department of Medicine and Epidemiology, School of Veterinary Medicine, University of California at Davis, \\ One Shields Avenue, Davis, CA 95616, USA; latell@ucdavis.edu \\ 3 Department of Pathology, Microbiology, and Immunology, School of Veterinary Medicine, University of \\ California at Davis, One Shields Avenue, Davis, CA 95616, USA; bbyrne@ucdavis.edu (B.A.B.); \\ kaclothier@ucdavis.edu (K.C.) \\ 4 California Animal Health and Food Safety Laboratory, University of California at Davis, One Shields \\ Avenue, Davis, CA 95616, USA \\ 5 Department of Biological Sciences, University of the Pacific, 3601 Pacific Avenue, Stockton, CA 95211, USA; \\ kland@pacific.edu \\ * Correspondence: jongheon.kim@ars.usda.gov; Tel.: +1-510-559-5841 \\ $+\quad$ This paper is an extended version of our paper published in Kim, J.H.; Chan, K.L.; Cheng, L.W.; Tell, L.A.; \\ Byrne, B.A.; Clothier, K.; Land, K.M. High Efficiency Drug Repurposing for New Antifungal Agents, \\ In Proceedings of 4th International Electronic Conference on Medicinal Chemistry, Basel, Switzerland, \\ 1-30 November 2018.
}

Received: 20 March 2019; Accepted: 12 April 2019; Published: 17 April 2019

\begin{abstract}
Current antifungal interventions have often limited efficiency in treating fungal pathogens, particularly those resistant to commercial drugs or fungicides. Antifungal drug repurposing is an alternative intervention strategy, whereby new utility of various marketed, non-antifungal drugs could be repositioned as novel antifungal agents. In this study, we investigated "chemosensitization" as a method to improve the efficiency of antifungal drug repurposing, wherein combined application of a second compound (viz., chemosensitizer) with a conventional, non-antifungal drug could greatly enhance the antifungal activity of the co-applied drug. Redox-active natural compounds or structural derivatives, such as thymol (2-isopropyl-5-methylphenol), 4-isopropyl-3-methylphenol, or 3,5-dimethoxybenzaldehyde, could serve as potent chemosensitizers to enhance antifungal activity of the repurposed drug bithionol. Of note, inclusion of fungal mutants, such as antioxidant mutants, could also facilitate drug repurposing efficiency, which is reflected in the enhancement of antifungal efficacy of bithionol. Bithionol overcame antifungal (viz., fludioxonil) tolerance of the antioxidant mutants of the human/animal pathogen Aspergillus fumigatus. Altogether, our strategy can lead to the development of a high efficiency drug repurposing design, which enhances the susceptibility of pathogens to drugs, reduces time and costs for new antifungal development, and abates drug or fungicide resistance.
\end{abstract}

Keywords: antifungal intervention; antioxidant system; Aspergillus; chemosensitization; drug repurposing; drug resistance; mutants; pathogen control

\section{Introduction}

There have been continuous efforts to develop new antifungal agents or to improve the efficacy of conventional antifungal methods [1,2]. However, current intervention strategies often have limited 
efficiency in treating fungi, especially those pathogens resistant to drugs or fungicides [3]. The use of high-throughput screenings/bioassays to develop new antifungal agents and/or define cellular targets of newly-identified antifungal agents is still a developing field. This is especially true with regard to determining the involvement of specific genes, genetic pathways or previously undetected lipid changes in cellular membranes, cross talks between lipid molecules and mitochondrial dysfunction, cell wall integrity and filamentous fungal growth, etc., which can explain resistance to conventional antifungal agents [4-7].

Recently, increased incidences of fungal resistance to a class of azoles make fungal infections a global human health issue [8]. Aspergillosis is an example. Aspergillosis is a fungal disease caused by filamentous fungal pathogens in the genus Aspergillus [9]. Immuno-compromised groups of people or patients with lung diseases are especially at risk of developing aspergillosis. Among the several types of aspergillosis documented (such as allergic bronchopulmonary aspergillosis, allergic Aspergillus sinusitis, aspergilloma, chronic pulmonary aspergillosis, invasive aspergillosis (IA), and cutaneous aspergillosis) [10], IA is a particularly devastating infection triggered by environmental Aspergillus species, wherein Aspergillus fumigatus is the leading agent of IA followed by A. flavus, A. terreus, A. niger, and $A$. nidulans $[9,10]$.

Certain azole fungicides, such as propiconazole or tebuconazole, that are applied to agricultural fields have the same mode of antifungal action as clinical azole drugs. Such long-term application of azole fungicides to fields could provide selection pressure for the emergence of pan-azole-resistant strains, such as the $A$. fumigatus TR34/L98H mutant [11,12]. As a result, there is a continuous need to improve the efficacy of current antifungal drugs or develop new intervention strategies. Of note, an invasive $A$. fumigatus infection (pulmonary) could also be acquired from contaminated foods, indicating IA further involves public food safety issue [13].

Considering the development of entirely new antifungal drugs is a capital-intensive and time-consuming process, an alternative approach termed "antifungal drug repurposing" has been recently investigated. Antifungal drug repurposing is the repositioning process of already marketed non-antifungal drugs - previously approved for treating other diseases-to control fungal infections [14]. One of the merits of drug repurposing is that the mechanisms of action, cellular targets or safety of the commercial drug has already been identified or characterized. However, although drug repurposing has become a viable approach to accelerate new antifungal drug development, this strategy still requires highly sensitive screening systems.

Meanwhile, antifungal "chemosensitization" has been developed as a new intervention method, where co-application of a second compound (viz., chemosensitizer; natural or synthetic), with a commercial drug has been found to enhance the antifungal efficacy of the co-applied drug [15]. The key advantage of chemosensitization is that, in contrast to combination therapy (viz., co-application of two or more commercial antifungal drugs), a chemosensitizer itself does not have to possess a high level of antifungal potency. Instead, a chemosensitizer causes the target pathogen to become more susceptible to the commercial co-applied drug by modulating the pathogen's defense system to the drug. Chemosensitization could also overcome fungal resistance to certain commercial antifungal drugs [15].

In this proof of concept study, we tried to develop a high-efficiency drug repurposing method by targeting the fungal antioxidant system. We applied a previously developed chemosensitization strategy by including redox-active natural compounds or a structural analog as sensitizers, and also used fungal mutants lacking key genes in the antioxidant system. This resulted in the enhancement of the efficacy of the repurposed pro-oxidant drug bithionol. Results indicated that the sensitivity of the drug repurposing process could be augmented by the chemosensitization method and/or inclusion of fungal mutants lacking key genes in the cellular targets. 


\section{Materials and Methods}

\subsection{Literature Search: PubMed Database}

Articles were retrieved via a PubMed search in the National Center for Biotechnology Information [16] (https://www.ncbi.nlm.nih.gov/) by using the key words "Drug Antifungal Repositioning" (Search date: May 31, 2018). The retrieved articles were re-evaluated further for the relevance of the contents to the subject antifungal drug development: Repositioning of non-antifungal drugs towards fungal control.

\subsection{Chemicals}

Chemical compounds, such as aspirin (acetyl salicylic acid), bithionol (2, 2'-sulfanediylbis (4, 6-dichlorophenol)), octyl gallate (octyl 3,4,5-trihydroxybenzoic acid; OG), thymol (2-isopropyl-5methylphenol; THY), 4-isopropyl-3-methylphenol (4I3M), and 3,5-dimethoxybenzaldehyde (3,5-D), were procured from Sigma Co. (St. Louis, MO, USA). Each compound was dissolved in dimethylsulfoxide (DMSO; absolute DMSO amount: $<2 \%$ in media) before incorporation into culture media. Throughout this study, controls (no treatment) contained DMSO at levels equivalent to that of cohorts receiving antifungal agents, within the same set of experiments.

\subsection{Antifungal Bioassay}

Antifungal activities of test compounds were examined in the wild type and two antioxidant mutants (sakA $\Delta, m p k C \Delta$ ) of the human pathogen Aspergillus fumigatus AF293 (see below for sources) and two mycotoxigenic fungi, Aspergillus parasiticus 2999 and A. parasiticus 5862 (National Center for Agricultural Utilization and Research, USDA-ARS, Peoria, IL, USA). Five $\mu$ L of each compound was spotted onto the lawn of test fungi $\left(1 \times 10^{4} \mathrm{cfu} / \mathrm{mL}\right.$; potato dextrose agar (PDA) plates), and fungi were incubated at $35^{\circ} \mathrm{C}$ for up to $48 \mathrm{hr}$. The formation of the zone of inhibition was monitored (with duplicates) at 24 and $48 \mathrm{hr}$ of incubation.

\subsection{Overcoming Fludioxonil Tolerance by Bithionol}

Determination of overcoming fludioxonil tolerance of $A$. fumigatus sak $A \Delta$ and $m p k C \Delta$ mutants was based on comparison of fungal radial growth between treated and control colonies. Fungal conidia $\left(5 \times 10^{3}\right)$ were diluted in phosphate buffered saline and inoculated as a drop onto the center of PDA plates (triplicates) containing: (1) No treatment (control); (2) Bithionol (125 $\mu \mathrm{M})$; (3) Fludioxonil $(50 \mu \mathrm{M})$; and (4) Bithionol + Fludioxonil. Growth was observed for 5 to 7 days at $35^{\circ} \mathrm{C}$.

\subsection{Statistical Analysis}

Statistical analysis (Student's $t$-test) was performed based on Reference [17], where $p<0.05$ was considered significant.

\section{Results and Discussion}

\subsection{Aspirin and Bithionol}

We initially performed a PubMed database search in the National Center for Biotechnology Information [16] (https://www.ncbi.nlm.nih.gov/) by using the key words "Drug Antifungal Repositioning" (Accessed on May 31, 2018), retrieving 70 articles. We re-evaluated the content of the retrieved articles for their relevance to antifungal drug development, identifying 16 articles (and references therein), which are shown in Table 1. The remaining 54 articles not selected described: (1) Antibacterial, antiviral, or antiprotozoal drug development; (2) anticancer drug development; and (3) drug development for other human diseases such as Parkinson's disease, hematologic malignancy, etc. Pharmacological information of the repurposed compounds is also provided in the supplementary Table S1 [18-38]. 
Table 1. Repositioning of non-antifungal drugs to antifungals.

\begin{tabular}{|c|c|c|c|c|}
\hline Compounds & Functions & Repositioning Methods & Target Fungi & References \\
\hline Bithionol & Anti-parasitic drug & $\begin{array}{l}\text { High-throughput ATP content } \\
\text { assays }\end{array}$ & Exserohilum rostratum & [39] \\
\hline Tacrolimus & Immunosuppressive agent & The same as above & E. rostratum & [39] \\
\hline Floxuridine & Antimetabolite & The same as above & E. rostratum & [39] \\
\hline Auranofin & Rheumatoid arthritis drug & $\begin{array}{l}\text { Clinical \& Laboratory Standard } \\
\text { Insitute (CLSI) M27-A3 protocol }\end{array}$ & $\begin{array}{c}\text { Candida and Cryptococcus } \\
\text { strains }\end{array}$ & [40] \\
\hline Drospirenone & $\begin{array}{l}\text { Synthetic hormone (birth control } \\
\text { pills) w/ethinylestradiol }\end{array}$ & $\begin{array}{l}\text { Enhancement of amphotericin } \\
\text { B/caspofungin activity against } \\
\text { Candida albicans biofilms (96-well } \\
\text { plate assay) }\end{array}$ & $\begin{array}{c}\text { C. albicans, } \\
\text { Candida glabrata }\end{array}$ & [42] \\
\hline Toremifine & $\begin{array}{l}\text { Selective oestrogen receptor } \\
\text { modulator (Oestrogen } \\
\text { receptor-positive breast cancer } \\
\text { treatment) }\end{array}$ & The same as above & The same as above & [42] \\
\hline $\begin{array}{c}\text { Aspirin } \\
\text { (Acetyl salicylic acid) }\end{array}$ & $\begin{array}{c}\text { Anti-pain, fever, or inflammation } \\
\text { drug }\end{array}$ & $\begin{array}{l}\text { European Committee on } \\
\text { Antimicrobial Susceptibility Testing } \\
\text { (EUCAST) protocol }\end{array}$ & $\begin{array}{l}\text { C. neoformans, } \\
\text { Cryptococcus gatti }\end{array}$ & [43] \\
\hline Ibuprofen & $\begin{array}{c}\text { Nonsteroidal anti-inflammatory } \\
\text { drug }\end{array}$ & The same as above & The same as above & [43] \\
\hline $\begin{array}{l}\text { Human glycogen synthase } \\
\text { kinase } 3 \text { (GSK-3) inhibitors }\end{array}$ & Neurological disorder drug & 24-well plate assay & A. fumigatus & [44] \\
\hline Thioridazine & Antipsychotic drug & The same as above & C. neoformans & [46] \\
\hline $\begin{array}{l}\text { Artesunate from } \\
\text { Pharmakon } 1600 \\
\text { repositioning library }\end{array}$ & Antimalarial drug & $\begin{array}{l}\text { Miconazole synergy test } \\
\text { (Anti-biofilm testing) }\end{array}$ & C. albicans & [47] \\
\hline Hexachlorophene & Anti-infective (topical) drug & The same as above & C. albicans & [47] \\
\hline Pyrvinium pamoate & Antihelmintic drug & The same as above & C. albicans & [47] \\
\hline Quinacrine & Anti-protozoan drug & 96-well plate anti-biofilm testing & C. albicans & [48] \\
\hline $\begin{array}{l}\text { Cyclo-Phosphamide } \\
\text { (plus } 28 \text { drugs) }\end{array}$ & Anti-cancer drug & 96-well anti-filamentation assay & C. albicans & [49] \\
\hline $\begin{array}{l}\text { Tosedostat from the Enzo } \\
\text { \& the Institute for } \\
\text { Molecular Medicine } \\
\text { Finland oncology } \\
\text { collection libraries }\end{array}$ & $\begin{array}{l}\text { Anti-cancer (Aminopeptidase } \\
\text { inhibitor) drug }\end{array}$ & EUCAST protocol. & $\begin{array}{l}\text { C. albicans, } \\
\text { C. glabrata }\end{array}$ & [14] \\
\hline Chloroquine & Anti-malarial drug & $\begin{array}{c}\text { Microtiter well plate } \\
\text { yeast-to-hyphae transition assay }\end{array}$ & C. albicans & [50] \\
\hline Aliskiren & Anti-hypertensive drug & CLSI M27-A2 protocol & C. albicans & [51] \\
\hline Atorvastatin & Anti-hypercholestero-laemia drug & CLSI M27-A3 protocol & C. gatti & [52] \\
\hline $\begin{array}{l}\text { P21-activated protein } \\
\text { kinase inhibitor }\end{array}$ & Anti-thyroid cancer drug & Agar plate bioassay & $\begin{array}{c}\text { Fusarium oxysporum, } \\
\text { Fusarium graminearium, } \\
\text { Phytopthora sp., } \\
\text { Myrothecium roridum, } \\
\text { Helminthosporium maydis. }\end{array}$ & [53] \\
\hline
\end{tabular}

We chose "aspirin" and "bithionol" as representative redox-active drugs (for targeting the fungal antioxidant system) for further investigation (Figure 1a,b). Aspirin (acetyl salicylic acid) is a non-steroidal anti-inflammatory agent, while bithionol is a halogenated anti-protozoal drug. Both aspirin and bithionol have been known to participate in reactive oxygen species (ROS)-mediated apoptosis (programmed cell death) in cancer cells [54,55]. Octyl gallate (OG) was used as a positive 
control, which is a redox-active agent (possessing antioxidant and pro-oxidant activity) interrupting the lipid bilayer-protein interface in fungal cells (Figure 1c).<smiles>CC(=O)Oc1ccccc1C(=O)O</smiles>

(a)<smiles>Cc1ccc(C(C)C)c(O)c1</smiles>

(d)<smiles>Oc1c(Cl)cc(Cl)cc1Sc1cc(Cl)cc(Cl)c1O</smiles>

(b)<smiles>CCCCOC(=O)c1cc(O)c(O)c(O)c1</smiles>

(c)<smiles>COc1cc(C=O)cc(OC)c1</smiles>

(f)

Figure 1. Structures of compounds examined in this study: (a) Aspirin; (b) bithionol; (c) octyl gallate; (d) thymol (2-isopropyl-5-methylphenol); (e) 4-isopropyl-3-methylphenol; (f) 3,5-dimethoxybenzaldehyde.

\subsection{Chemosensitization to Enhance the Efficacy of Repurposed Drugs}

Figure 1d,e show examples of chemosensitizers used in this study for targeting fungal antioxidant systems. Thymol (2-isopropyl-5-methylphenol) is a redox-active natural compound, and 4-isopropyl-3-methylphenol (4I3M) is a synthetic analog of thymol. We performed zone of inhibition bioassays, and compared the antifungal efficacy of repurposed drugs for wild type, antioxidant mutants, wild type with chemosensitizers, and antioxidant mutants with chemosensitizers.

Of note, the antioxidant systems of fungi, such as the mitogen-activated protein kinase (MAPK) signaling pathway, have been effective antifungal targets of redox-active agents. For instance, A. fumigatus sakA $\Delta$ and mpkC $\Delta$ are mutants lacking antioxidant MAPK genes [56,57]. Previous studies have shown that $A$. fumigatus sak $A \Delta$ and mpkC $\Delta$ mutants are highly susceptible to redox-active drugs such as amphotericin B or itraconazole compared to the wild type strain $[58,59]$.

\subsubsection{Thymol as a Chemosensitizer to Bithionol or Aspirin}

Results showed that antifungal activity of bithionol was greatly enhanced by thymol, while that of aspirin was almost not affected, indicating "drug-chemosensitizer specificity" exists for the enhancement of antifungal activity (Figure 2). Drugs were tested at 32 to $1024 \mu \mathrm{M}$, with or without $0.6 \mathrm{mM}$ of thymol, and the positive control OG was tested at 1 and $5 \mathrm{mM}$. The results also showed that A. fumigatus MAPK mutants ( $s a k A \Delta, m p k C \Delta$ ) were more susceptible to the treatment compared to the wild type, indicating increased susceptibility of antioxidant mutants to the co-application of redox-active agents, such as thymol.

Bithionol is an anti-parasitic, "pro-oxidant" drug approved previously by the Food and Drug Administration [60]. It has recently been shown that co-application of bithionol sensitized ovarian cancer cells to paclitaxel, thus requiring lower doses of paclitaxel for cancer treatment [54]. Bithionol synergistically interacted with paclitaxel, where the combined application (bithionol + paclitaxel) increased the generation of ROS and also enhanced apoptosis in cancer cells [54]. In cancer therapy, generation of ROS is the key mechanism of apoptosis for chemotherapeutic reagents. Therefore, increased generation of cellular ROS via combined application of chemotherapeutic drugs with bithionol contributed to the enhancement of cancer therapy [54]. Co-application of bithionol could also mitigate the toxic side-effects associated with the high dose treatment of the drug paclitaxel [54]. 
A similar phenomenon was also observed with the anticancer drug cisplatin, where bithionol augmented the susceptibility of cisplatin-resistant cell lines to the drug by increasing ROS generation in the cells [61].

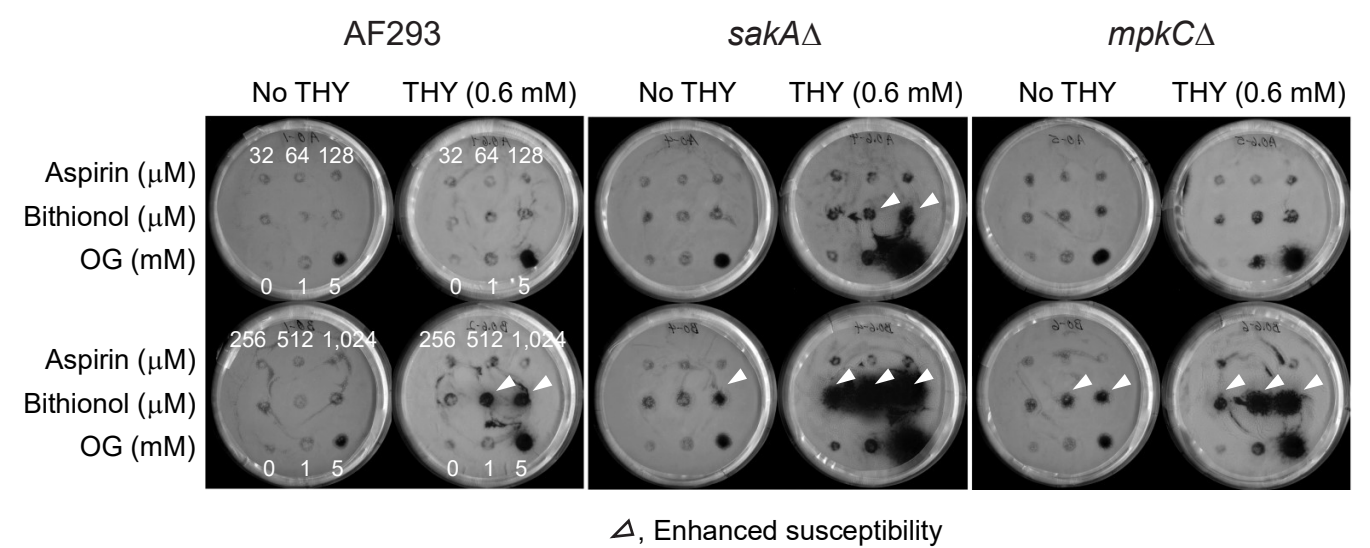

Figure 2. Enhancement of antifungal activity of bithionol by thymol tested in A. fumigatus. THY, thymol; OG, octyl gallate (positive control).

On the other hand, although aspirin has been shown to participate in ROS-mediated apoptosis in cancer cells, aspirin played a role as an "antioxidant" until the start of apoptosis in cells, thereby indicating ROS were not the major factors to trigger apoptosis in aspirin-treated cells [55].

Thymol is a redox-active agent, and therefore acts as an antioxidant at lower concentrations. At higher concentrations, it functions as a pro-oxidant, inducing oxidative stress in the Caco-2 cell line [62]. We speculate that, as observed in anticancer therapy, combined application of bithionol and the redox-active thymol could synergize to enhance cellular oxidative stress, which resulted in increased sensitivity of fungi (i.e., enhanced zone of inhibition, Figure 2) to the treatments, especially in mutants having defects in antioxidant systems.

\subsubsection{4-Isopropyl-3-Methylphenol as a Chemosensitizer to Bithionol or Aspirin}

The level of bithionol activity was enhanced further when 4I3M, a structural analog of thymol, was co-applied as a chemosensitizer (Figure 3). For example, the zone of inhibition with 4I3M was detected at a much lower concentration of bithionol, namely 32 to $128 \mu \mathrm{M}$, while that with thymol was detected at 512 to $1024 \mu \mathrm{M}$ of bithionol. Also, the sizes of zone of inhibition with 4I3M were larger than that with thymol. Therefore, results indicated that $4 \mathrm{I} 3 \mathrm{M}$ could be more effective chemosensitizer to bithionol, when compared to thymol in A. fumigatus (Figure 3). As observed in thymol, the activity of aspirin was almost not affected by co-treatment with $4 \mathrm{I} 3 \mathrm{M}$.

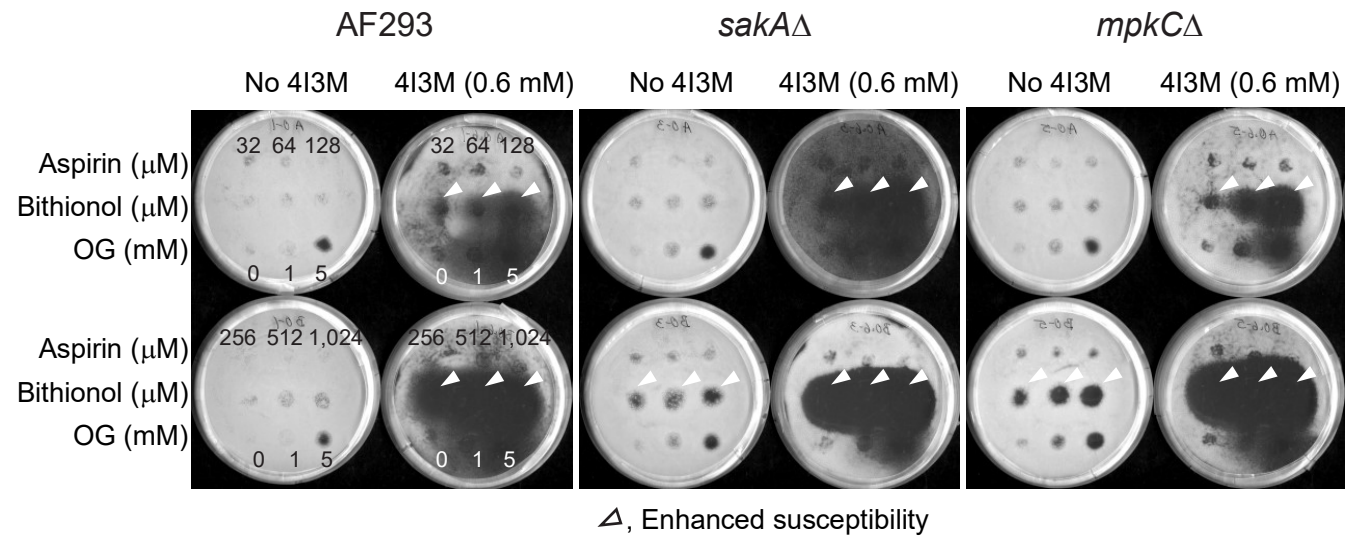

Figure 3. Enhancement of antifungal activity of bithionol by $4 \mathrm{I} 3 \mathrm{M}$ tested in A. fumigatus. 4I3M, 4-isopropyl-3-methylphenol; OG, octyl gallate (positive control). 
Recent studies showed that the yeast Saccharomyces cerevisiae has served as a useful system for the identification of new antifungal agents and their cellular targets in view that: (1) The S. cerevisiae genome has been sequenced and well annotated [63], and (2) around 6,000 haploid gene deletion mutant collections of $S$. cerevisiae have been the tool for determining drug mode of action [64-66]. Aspergillus species and the model yeast $S$. cerevisiae also share high homology in the structure of their antioxidant MAPK signaling systems [67]. This means the genetic or genomic resources of S. cerevisiae, such as gene deletion mutants of the yeast, could serve as tools for drug screening for control of Aspergillus species [64-66].

Yeast dilution bioassay in a prior study showed the "sensitive" responses of yeast vacuolar and antioxidant gene deletion mutants to 4I3M, indicating 4I3M negatively affects both cellular ion and "redox" homeostasis in fungi [68]. We previously observed similar results with thymol [58], further indicating $4 \mathrm{I} 3 \mathrm{M}$ and thymol share analogous cellular targets in fungi. $4 \mathrm{I} 3 \mathrm{M}$ is a synthetic analog of thymol, a natural product. As with thymol, $4 \mathrm{I} 3 \mathrm{M}$ has been used as an antimicrobial preservative in personal care products, where $4 \mathrm{I} 3 \mathrm{M}$ is more appealing to consumer perception compared to thymol due to its color/odor-neutral characteristic [68].

We applied the same strategy in Aspergillus parasiticus, a mycotoxigenic fungus producing hepato-carcinogenic aflatoxins. Chemosensitization effects of thymol or $4 \mathrm{I} 3 \mathrm{M}$ to bithionol were also observed in A. parasiticus (Figure 4). However, unlike in A. fumigatus, thymol exhibited higher sensitizing activity compared to its analog 4I3M in A. parasiticus (Figure 4). Also, the sizes of zone of inhibition in A. parasiticus were generally smaller than that observed in A. fumigatus, indicating "strain-specificity" also exists for the efficacy of chemosensitization when bithionol is co-applied with thymol or 4I3M.

\section{A. parasiticus 2999}

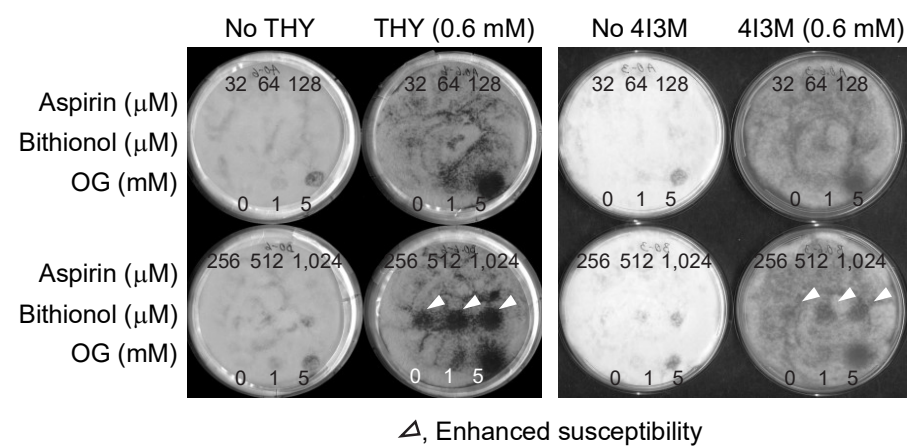

Figure 4. Enhancement of antifungal activity of bithionol by thymol or 4I3M tested in the aflatoxigenic A. parasiticus 2999. THY, thymol; 4I3M, 4-isopropyl-3-methylphenol; OG, octyl gallate (positive control).

A. fumigatus is a human/animal pathogen, while A. parasiticus mostly contaminates crops or foods. We recently observed that $A$. fumigatus was able to survive at high temperature $\left(55^{\circ} \mathrm{C}\right)$, while A. parasiticus could not grow at the same temperature [69]. Although such differences in niches and/or environmental responsiveness might contribute to the "strain-specificity" determined in this study, elucidation of precise mechanisms exerting strain-specificity warrants future investigation.

\subsubsection{3,5-Dimethoxybenzaldehyde as a Chemosensitizer to Bithionol or Aspirin}

We investigated the effect of other types of chemosensitizer for the enhancement of bithionol activity. The 3,5-dimethoxybenzaldehyde (3,5-D) (Figure 1f) also targets antioxidant systems in fungi, as determined in the model yeast S. cerevisiae (Supplementary Table S2 [59,70]). 3,5-D negatively affected the cellular antioxidant system, such as superoxide dismutase or glutathione reductase [59].

As determined in thymol or 4I3M co-treatment, antifungal activity of bithionol was also enhanced when the drug was co-applied with 3,5-D (Figure 5). Similar to thymol or 4I3M co-treatment, antifungal activity of aspirin was almost unaffected when 3,5-D was co-applied as a chemosensitizer (Figure 5). 
In general, the level of the enhancement of bithionol activity with 3,5-D was lower than that observed with thymol or $4 \mathrm{I} 3 \mathrm{M}$, which was reflected in smaller sizes of zone of inhibition.

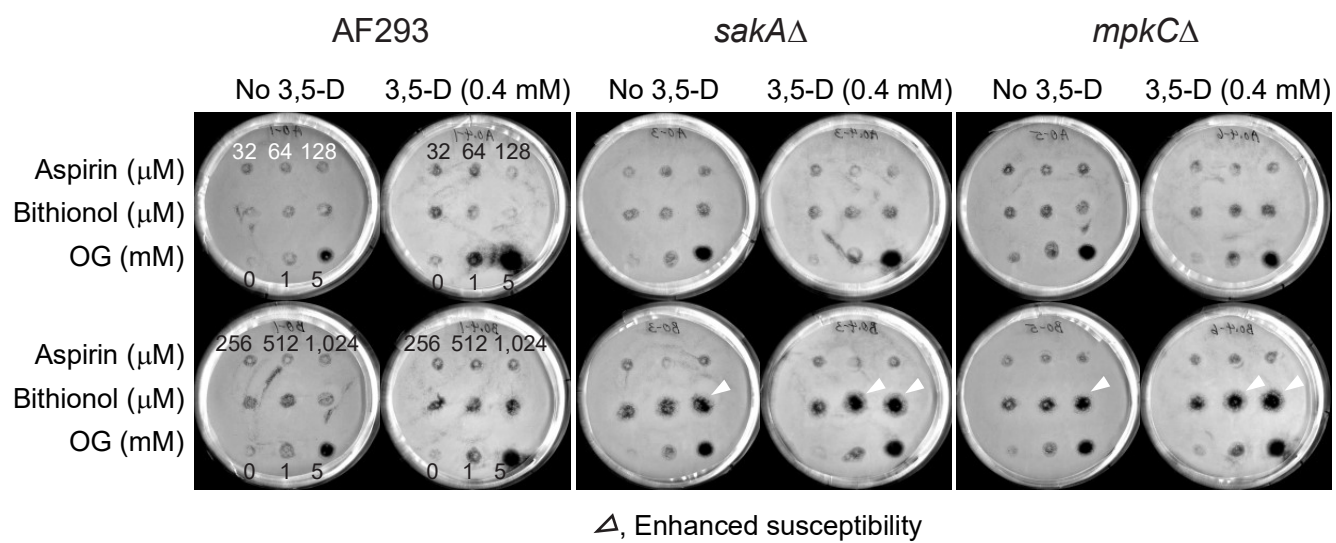

Figure 5. Enhancement of antifungal activity of bithionol by 3,5-dimethoxybenzaldehyde tested in A. fumigatus. 3,5-D, 3,5-dimethoxybenzaldehyde; OG, octyl gallate (positive control).

Similar results were obtained in the aflatoxin-producing $A$. parasiticus, where the sizes of zone of inhibition were generally smaller than that observed in A. fumigatus. Therefore, results indicated that "strain-specificity" also existed for the enhancement of the efficacy of "bithionol and 3,5-dimethoxybenzaldehyde" co-treatment in different Aspergillus species (Figure 6).

\section{A. parasiticus 5862}

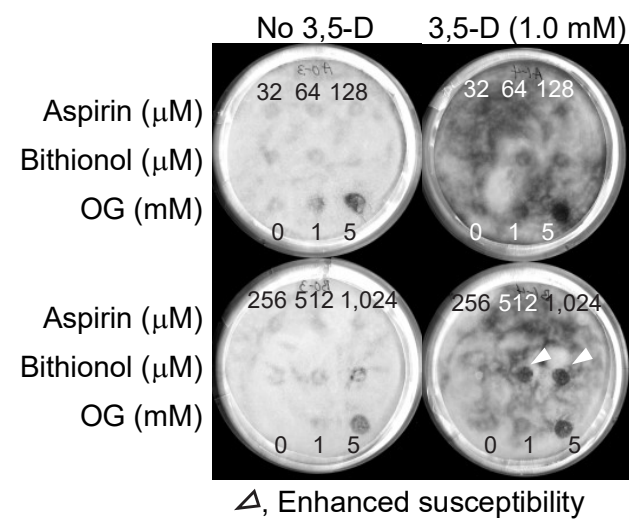

Figure 6. Enhancement of the antifungal activity of bithionol by 3,5-dimethoxybenzaldehyde tested in the aflatoxigenic $A$. parasiticus 5862. 3,5-D, 3,5-dimethoxybenzaldehyde; OG, octyl gallate (positive control).

We also speculate that quantitation of the precise level of interactions between compounds-such as synergistic, additive, neutral or antagonistic interactions-during chemosensitization can be determined in future investigations by the methods outlined by the Clinical Laboratory Standards Institute (CLSI) M38-A [71] or the European Committee on Antimicrobial Susceptibility Testing (EUCAST) [72]; definitive document EDef 7.2.].

\subsection{Scheme of High-Efficiency Drug Repurposing Design}

Figure 7 describes the scheme of high-efficiency drug repurposing design based on the current investigation, which targets the fungal antioxidant system. When the wild type strain is used during the drug repurposing process, it is considered a "low sensitivity" screening, and thus we expect to obtain a small number of repurposed drugs. When mutants, such as antioxidant mutants, are used or the wild type is used with redox-active sensitizing agents, it is considered a "medium sensitivity" 
screening, and thus we expect to obtain a medium number of repurposed drugs. When antioxidant mutants are used with redox-active chemosensitizers, it is considered a "high sensitivity" screening, so that we expect the isolation of a large number of repurposed drugs.

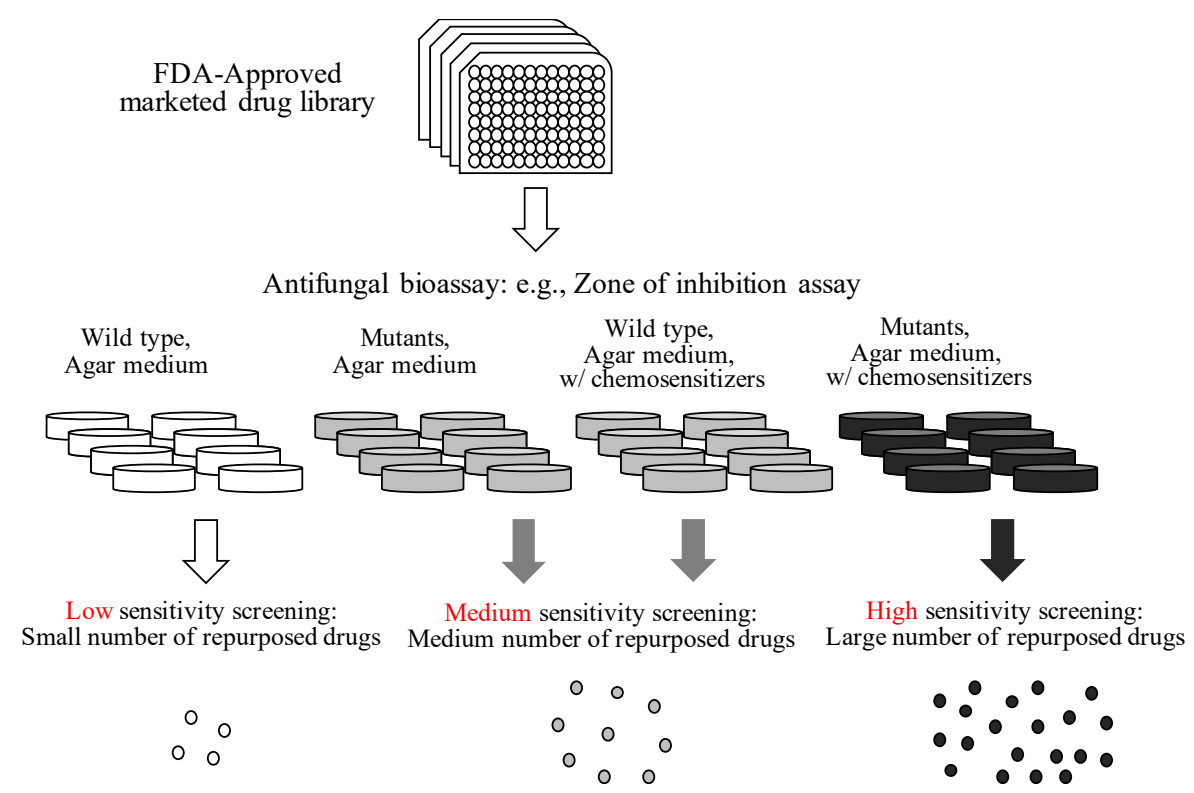

Figure 7. Scheme of high-efficiency drug repurposing design.

Regarding the chemosensitizers, we speculated that (as determined in this study with thymol/4I3M and bithionol) application of chemosensitizers with similar modes of action or cellular targets as the candidate drugs (e.g., pro-oxidant + pro-oxidant, cell wall/membrane disruptors + cell wall/membrane disruptors, etc.) would result in higher sensitivity of the drug repurposing process. Examples of antifungal chemosensitizers identified include: (a) 4-methoxy-2,3,6-trimethylbenzensulfonyl- substituted $d$-octapeptide sensitizing Candida strains to fluconazole [73]; (b) 7-chlorotetrazolo [5,1-c]benzo [1,2,4]triazine sensitizing Candida and Saccharomyces strains to azole drugs [74]; and (c) benzhydroxamic acid sensitizing Rhizopus oryzae to triazoles, such as posaconazole and itraconazole [75] (see also Supplementary Table S2 [59,69,70,76]). Identification of comprehensive numbers of chemosensitizers affecting different cellular targets also requires future in-depth study.

\subsection{Overcoming Fludioxonil Tolerance of Aspergillus Fumigatus MAPK Mutants}

Fludioxonil (phenylpyrrole) is a commercial antifungal agent, which induces abnormal and excessive stimulation of the oxidative stress MAPK signaling system [77]. However, fungi having mutations in oxidative stress MAPK pathway can escape the fludioxonil toxicity [77]. As shown in Figure 8, two MAPK mutants ( $\operatorname{sak} A \Delta, m p k C \Delta$ ) of $A$. fumigatus exhibited tolerance to fludioxonil at $50 \mu \mathrm{M}$, and developed radial growth on PDA, while the growth of the wild type was completely disrupted. However, co-application of sub-fungicidal concentration of bithionol with fludioxonil effectively prevented fungal tolerance to fludioxonil, therefore achieving complete inhibition of the growth of two MAPK mutants. The Student's $t$-test for paired data (combined, i.e., bithionol + fludioxonil) was versus bithionol alone or fludioxonil alone and determined in sakA $\Delta$ and $m p k C \Delta$ strains, where the $p$ values for "combined" were determined as $<0.005$ for both versus bithionol only and fludioxonil only. 


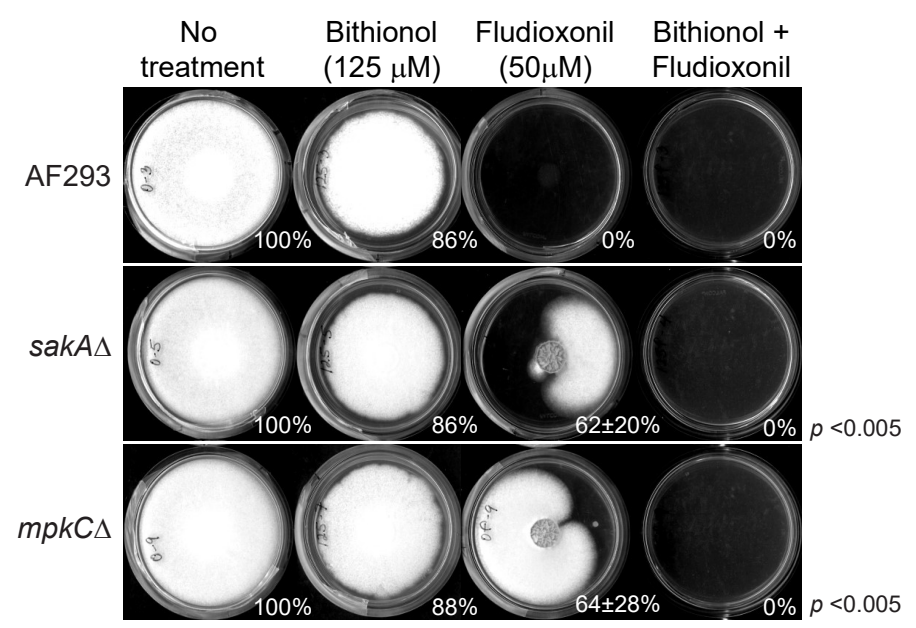

Figure 8. Bithionol overcomes fludioxonil resistance of Aspergillus fumigatus MAPK mutants.

In fungi, environmental signals, such as oxidative stress signals, are integrated into the MAPK signaling system, regulating the expression of downstream genes that are countering the stress [78,79]. Therefore, we speculate that, by co-applying a pro-oxidant agent (such as bithionol) with fludioxonil, these tolerant MAPK mutants became more susceptible to the treatment, since the mutated MAPK system of fungi was incapable of initiating a fully operational oxidative stress response including the production of antioxidant enzymes.

\section{Conclusions}

In summary, a high sensitivity antifungal screening method was investigated by incorporating redox-active chemosensitizers and antioxidant mutants of $A$. fumigatus. Redox-active compounds, such as thymol, $4 \mathrm{I} 3 \mathrm{M}$ or 3,5-D, can be used as potent chemosensitizers to enhance antimycotic activity of the repurposed drug bithionol, while the efficacy of the other drug aspirin was almost not affected, indicating "chemosensitizer-drug specificity" exists. The difference in antifungal efficacy between bithionol and aspirin could be based on their role as either "pro-oxidant (bithionol)" or "antioxidant (aspirin)" during treatments (see above). While similar enhancement of antifungal efficacy was also observed in the mycotoxin-producing $A$. parasiticus, the level of sensitivity of this species to the treatments was not comparable to that of A. fumigatus, thus indicating "strain-specificity" also exists during chemosensitization. Application of compounds with similar mechanisms of action (e.g., pro-oxidant, cell wall/membrane disruptors, etc.) or cellular targets (e.g., antioxidant system, cell wall/membrane integrity system, etc.) to that of the candidate drugs is suggested, which would result in higher sensitivity of the drug repurposing process.

Current results could be used for the development of high-efficiency, large-scale repositioning of marketed drugs, which can reduce costs, abate resistance, and alleviate negative side effects associated with current antifungal treatments. Inclusion of additional databases, such as DrugCentral [80] and Aggregate Analysis of ClinicalTrials.gov (AACT) [81], etc., might enhance the comprehensiveness of antifungal drug repositioning in the future study.

Supplementary Materials: The following are available online at http://www.mdpi.com/2409-9279/2/2/31/s1, Table S1: Pharmacology of repositioned compounds, Table S2: Examples of chemosensitizers targeting antioxidant or cell wall systems in fungi previously determined in the model yeast Saccharomyces cerevisiae.

Author Contributions: J.H.K. conceived, designed and performed research including data analysis and interpretation, literature search, and wrote the manuscript. K.L.C. performed antifungal bioassays and prepared the figures. L.A.T., B.A.B., K.C. and K.M.L. performed data analysis and interpretation, and revised the manuscript. L.W.C., Research Leader, directed the research. 
Acknowledgments: This research was conducted under USDA-ARS CRIS Project 5325-42000-039-00D. Part of this study has been presented at the 4th International Electronic Conference on Medicinal Chemistry, November 1 to 30, 2018 (https://ecmc-4.sciforum.net/).

Conflicts of Interest: The authors declare no conflict of interest.

\section{References}

1. Nami, S.; Aghebati-Maleki, A.; Morovati, H.; Aghebati-Maleki, L. Current antifungal drugs and immunotherapeutic approaches as promising strategies to treatment of fungal diseases. Biomed. Pharmacother. 2019, 110, 857-868. [CrossRef] [PubMed]

2. Nicola, A.M.; Albuquerque, P.; Paes, H.C.; Fernandes, L.; Costa, F.F.; Kioshima, E.S.; Abadio, A.K.R.; Bocca, A.L.; Felipe, M.S. Antifungal drugs: New insights in research \& development. Pharmacol. Ther. 2018. [CrossRef]

3. Beardsley, J.; Halliday, C.L.; Chen, S.C.-A.; Sorrell, T.C. Responding to the emergence of antifungal drug resistance: Perspectives from the bench and the bedside. Future Microbiol. 2018, 13, 1175-1191. [CrossRef] [PubMed]

4. Meir, Z.; Osherov, N. Vitamin Biosynthesis as an Antifungal Target. J. Fungi 2018, 4, 72. [CrossRef]

5. Prasad, R.; Shah, A.H.; Rawal, M.K. Antifungals: Mechanism of Action and Drug Resistance. Adv. Exp. Med. Biol. 2016, 892, 327-349. [CrossRef] [PubMed]

6. Prasad, R.; Singh, A. Lipids of Candida albicans and their role in multidrug resistance. Curr. Genet. 2013, 59, 243-250. [CrossRef]

7. Wiederhold, N.P. Antifungal resistance: Current trends and future strategies to combat. Infect Drug Resist. 2017, 10, 249-259. [CrossRef] [PubMed]

8. McCarthy, M.W.; Kontoyiannis, D.P.; Cornely, O.A.; Perfect, J.R.; Walsh, T.J. Novel agents and drug targets to meet the challenges of resistant fungi. J. Infect. Dis. 2017, 216, S474-S483. [CrossRef]

9. Maschmeyer, G.; Haas, A.; Cornely, O.A. Invasive aspergillosis: Epidemiology, diagnosis and management in immunocompromised patients. Drugs 2007, 67, 1567-1601. [CrossRef]

10. Rivero-Menendez, O.; Alastruey-Izquierdo, A.; Mellado, E.; Cuenca-Estrella, M. Triazole resistance in Aspergillus spp.: A worldwide problem? J. Fungi 2016, 2, 21. [CrossRef]

11. Bowyer, P.; Denning, D.W. Environmental fungicides and triazole resistance in Aspergillus. Pest Manag. Sci. 2014, 70, 173-178. [CrossRef] [PubMed]

12. Chowdhary, A.; Kathuria, S.; Xu, J.; Sharma, C.; Sundar, G.; Singh, P.K.; Gaur, S.N.; Hagen, F.; Klaassen, C.H.; Meis, J.F. Clonal expansion and emergence of environmental multiple-triazole-resistant Aspergillus fumigatus strains carrying the TR(3)(4)/L98H mutations in the cyp51A gene in India. PLoS ONE 2012, 7, e52871. [CrossRef]

13. Benedict, K.; Chiller, T.M.; Mody, R.K. Invasive fungal infections acquired from contaminated food or nutritional supplements: A review of the literature. Foodborne Pathog. Dis. 2016, 13, 343-349. [CrossRef] [PubMed]

14. Stylianou, M.; Kulesskiy, E.; Lopes, J.P.; Granlund, M.; Wennerberg, K.; Urban, C.F. Antifungal application of nonantifungal drugs. Antimicrob. Agents Chemother. 2014, 58, 1055-1062. [CrossRef] [PubMed]

15. Campbell, B.C.; Chan, K.L.; Kim, J.H. Chemosensitization as a means to augment commercial antifungal agents. Front. Microbiol. 2012, 3, 79. [CrossRef]

16. National Center for Biotechnology Information. PubMed. Available online: https://www.ncbi.nlm.nih.gov/ pubmed (accessed on 31 May 2018).

17. Kirkman, T.W. Statistics to Use. Available online: http://www.physics.csbsju.edu/stats/ (accessed on 4 February 2019).

18. Kleinboelting, S.; Ramos-Espiritu, L.; Buck, H.; Colis, L.; van den Heuvel, J.; Glickman, J.F.; Levin, L.R.; Buck, J.; Steegborn, C. Bithionol potently inhibits human soluble adenylyl cyclase through binding to the allosteric activator site. J. Biol. Chem. 2016, 291, 9776-9784. [CrossRef]

19. National Center for Biotechnology Information. PubChem Compound Database; CID=445643. Available online: https://pubchem.ncbi.nlm.nih.gov/compound/445643 (accessed on 30 January 2019).

20. National Center for Biotechnology Information. PubChem Compound Database; CID=5790. Available online: https://pubchem.ncbi.nlm.nih.gov/compound/5790 (accessed on 30 January 2019). 
21. National Center for Biotechnology Information. PubChem Compound Database; CID=16667669. Available online: https://pubchem.ncbi.nlm.nih.gov/compound/16667669 (accessed on 30 January 2019).

22. National Center for Biotechnology Information. PubChem Compound Database; CID=68873. Available online: https://pubchem.ncbi.nlm.nih.gov/compound/68873 (accessed on 30 January 2019).

23. National Center for Biotechnology Information. PubChem Compound Database; CID=4746. Available online: https://pubchem.ncbi.nlm.nih.gov/compound/4746 (accessed on 30 January 2019).

24. National Center for Biotechnology Information. PubChem Compound Database; CID=3005573. Available online: https://pubchem.ncbi.nlm.nih.gov/compound/3005573 (accessed on 30 January 2019).

25. National Center for Biotechnology Information. PubChem Compound Database; CID=2244. Available online: https://pubchem.ncbi.nlm.nih.gov/compound/2244 (accessed on 30 January 2019).

26. National Center for Biotechnology Information. PubChem Compound Database; CID=3672. Available online: https://pubchem.ncbi.nlm.nih.gov/compound/3672 (accessed on 30 January 2019).

27. National Center for Biotechnology Information. PubChem Compound Database; CID=10982. Available online: https://pubchem.ncbi.nlm.nih.gov/compound/10982\#section=Biological-Test-Results (accessed on 30 January 2019).

28. National Center for Biotechnology Information. PubChem Compound Database; CID=2157. Available online: https://pubchem.ncbi.nlm.nih.gov/compound/2157 (accessed on 30 January 2019).

29. National Center for Biotechnology Information. PubChem Compound Database; CID=5452. Available online: https://pubchem.ncbi.nlm.nih.gov/compound/5452 (accessed on 30 January 2019).

30. National Center for Biotechnology Information. PubChem Compound Database; CID=6917864. Available online: https://pubchem.ncbi.nlm.nih.gov/compound/6917864 (accessed on 30 January 2019).

31. National Center for Biotechnology Information. PubChem Compound Database; CID=3598. Available online: https://pubchem.ncbi.nlm.nih.gov/compound/3598 (accessed on 30 January 2019).

32. National Center for Biotechnology Information. PubChem Compound Database; CID=54680693. Available online: https://pubchem.ncbi.nlm.nih.gov/compound/54680693\#section=Pharmacology-and-Biochemistry (accessed on 30 January 2019).

33. National Center for Biotechnology Information. PubChem Compound Database; CID=237. Available online: https://pubchem.ncbi.nlm.nih.gov/compound/237 (accessed on 30 January 2019).

34. National Center for Biotechnology Information. PubChem Compound Database; CID=2907. Available online: https://pubchem.ncbi.nlm.nih.gov/compound/2907 (accessed on 30 January 2019).

35. National Center for Biotechnology Information. PubChem Compound Database; CID=15547703. Available online: https://pubchem.ncbi.nlm.nih.gov/compound/15547703 (accessed on 30 January 2019).

36. National Center for Biotechnology Information. PubChem Compound Database; CID=2719. Available online: https://pubchem.ncbi.nlm.nih.gov/compound/2719 (accessed on 30 January 2019).

37. National Center for Biotechnology Information. PubChem Compound Database; CID=5493444. Available online: https://pubchem.ncbi.nlm.nih.gov/compound/5493444 (accessed on 30 January 2019).

38. National Center for Biotechnology Information. PubChem Compound Database; CID=60823. Available online: https://pubchem.ncbi.nlm.nih.gov/compound/60823 (accessed on 30 January 2019).

39. Sun, W.; Park, Y.D.; Sugui, J.A.; Fothergill, A.; Southall, N.; Shinn, P.; McKew, J.C.; Kwon-Chung, K.J.; Zheng, W.; Williamson, P.R. Rapid identification of antifungal compounds against Exserohilum rostratum using high throughput drug repurposing screens. PLoS ONE 2013, 8, e70506. [CrossRef]

40. Thangamani, S.; Maland, M.; Mohammad, H.; Pascuzzi, P.E.; Avramova, L.; Koehler, C.M.; Hazbun, T.R.; Seleem, M.N. Repurposing approach identifies auranofin with broad spectrum antifungal activity that targets Mia40-Erv1 pathway. Front. Cell. Infect. Microbiol. 2017, 7, 4. [CrossRef]

41. Wiederhold, N.P.; Patterson, T.F.; Srinivasan, A.; Chaturvedi, A.K.; Fothergill, A.W.; Wormley, F.L.; Ramasubramanian, A.K.; Lopez-Ribot, J.L. Repurposing auranofin as an antifungal: In vitro activity against a variety of medically important fungi. Virulence 2017, 8, 138-142. [CrossRef]

42. Delattin, N.; De Brucker, K.; Vandamme, K.; Meert, E.; Marchand, A.; Chaltin, P.; Cammue, B.P.; Thevissen, K. Repurposing as a means to increase the activity of amphotericin B and caspofungin against Candida albicans biofilms. J. Antimicrob. Chemother. 2014, 69, 1035-1044. [CrossRef]

43. Ogundeji, A.O.; Pohl, C.H.; Sebolai, O.M. Repurposing of aspirin and ibuprofen as candidate anti-Cryptococcus drugs. Antimicrob. Agents Chemother. 2016, 60, 4799-4808. [CrossRef] [PubMed] 
44. Sebastian-Perez, V.; Manoli, M.T.; Perez, D.I.; Gil, C.; Mellado, E.; Martinez, A.; Espeso, E.A.; Campillo, N.E. New applications for known drugs: Human glycogen synthase kinase 3 inhibitors as modulators of Aspergillus fumigatus growth. Eur. J. Med. Chem. 2016, 116, 281-289. [CrossRef]

45. Kim, K.; Zilbermintz, L.; Martchenko, M. Repurposing FDA approved drugs against the human fungal pathogen, Candida albicans. Ann. Clin. Microbiol. Antimicrob. 2015, 14, 32. [CrossRef] [PubMed]

46. Butts, A.; DiDone, L.; Koselny, K.; Baxter, B.K.; Chabrier-Rosello, Y.; Wellington, M.; Krysan, D.J. A repurposing approach identifies off-patent drugs with fungicidal cryptococcal activity, a common structural chemotype, and pharmacological properties relevant to the treatment of cryptococcosis. Eukaryot. Cell 2013, 12, 278-287. [CrossRef] [PubMed]

47. De Cremer, K.; Lanckacker, E.; Cools, T.L.; Bax, M.; De Brucker, K.; Cos, P.; Cammue, B.P.; Thevissen, K. Artemisinins, new miconazole potentiators resulting in increased activity against Candida albicans biofilms. Antimicrob. Agents Chemother. 2015, 59, 421-426. [CrossRef]

48. Kulkarny, V.V.; Chavez-Dozal, A.; Rane, H.S.; Jahng, M.; Bernardo, S.M.; Parra, K.J.; Lee, S.A. Quinacrine inhibits Candida albicans growth and filamentation at neutral pH. Antimicrob. Agents Chemother. 2014, 58, 7501-7509. [CrossRef] [PubMed]

49. Routh, M.M.; Chauhan, N.M.; Karuppayil, S.M. Cancer drugs inhibit morphogenesis in the human fungal pathogen, Candida albicans. Braz. J. Microbiol. 2013, 44, 855-859. [CrossRef]

50. Shinde, R.B.; Rajput, S.B.; Raut, J.S.; Karuppayil, S.M. An in vitro repositioning study reveals antifungal potential of chloroquine to inhibit growth and morphogenesis in Candida albicans. J. Gen. Appl. Microbiol. 2013, 59, 167-170. [CrossRef]

51. Kathwate, G.H.; Karuppayil, S.M. Antifungal properties of the anti-hypertensive drug: Aliskiren. Arch. Oral. Biol. 2013, 58, 1109-1115. [CrossRef]

52. Ribeiro, N.Q.; Costa, M.C.; Magalhaes, T.F.F.; Carneiro, H.C.S.; Oliveira, L.V.; Fontes, A.C.L.; Santos, J.R.A.; Ferreira, G.F.; Araujo, G.R.S.; Alves, V.; et al. Atorvastatin as a promising anticryptococcal agent. Int. J. Antimicrob. Agents 2017, 49, 695-702. [CrossRef]

53. Ma, Y.; Liang, S.; Zhang, Y.; Yang, D.; Wang, R. Development of anti-fungal pesticides from protein kinase inhibitor-based anticancer agents. Eur. J. Med. Chem. 2018, 148, 349-358. [CrossRef] [PubMed]

54. Ayyagari, V.N.; Diaz-Sylvester, P.L.; Hsieh, T.J.; Brard, L. Evaluation of the cytotoxicity of the bithionol-paclitaxel combination in a panel of human ovarian cancer cell lines. PLOS ONE 2017, 12, e0185111. [CrossRef] [PubMed]

55. Balzan, R.; Sapienza, K.; Galea, D.R.; Vassallo, N.; Frey, H.; Bannister, W.H. Aspirin commits yeast cells to apoptosis depending on carbon source. Microbiology 2004, 150, 109-115. [CrossRef]

56. Reyes, G.; Romans, A.; Nguyen, C.K.; May, G.S. Novel mitogen-activated protein kinase MpkC of Aspergillus fumigatus is required for utilization of polyalcohol sugars. Eukaryot. Cell 2006, 5, 1934-1940. [CrossRef] [PubMed]

57. Xue, T.; Nguyen, C.K.; Romans, A.; May, G.S. A mitogen-activated protein kinase that senses nitrogen regulates conidial germination and growth in Aspergillus fumigatus. Eukaryot. Cell 2004, 3, 557-560. [CrossRef] [PubMed]

58. Kim, J.H.; Chan, K.L.; Faria, N.C.; Martins Mde, L.; Campbell, B.C. Targeting the oxidative stress response system of fungi with redox-potent chemosensitizing agents. Front. Microbiol. 2012, 3, 88. [CrossRef] [PubMed]

59. Kim, J.H.; Chan, K.L.; Mahoney, N.; Campbell, B.C. Antifungal activity of redox-active benzaldehydes that target cellular antioxidation. Ann. Clin. Microbiol. Antimicrob. 2011, 10, 23. [CrossRef] [PubMed]

60. Bacq, Y.; Besnier, J.M.; Duong, T.H.; Pavie, G.; Metman, E.H.; Choutet, P. Successful treatment of acute fascioliasis with bithionol. Hepatology 1991, 14, 1066-1069. [CrossRef] [PubMed]

61. Ayyagari, V.N.; Brard, L. Bithionol inhibits ovarian cancer cell growth in vitro - studies on mechanism(s) of action. BMC Cancer 2014, 14, 61. [CrossRef]

62. Llana-Ruiz-Cabello, M.; Gutierrez-Praena, D.; Puerto, M.; Pichardo, S.; Jos, A.; Camean, A.M. In vitro pro-oxidant/antioxidant role of carvacrol, thymol and their mixture in the intestinal Caco-2 cell line. Toxicol. In Vitro 2015, 29, 647-656. [CrossRef]

63. Saccharomyces Genome Database. Available online: www.yeastgenome.org (accessed on 4 February 2019). 
64. Lee, A.Y.; St.Onge, R.P.; Proctor, M.J.; Wallace, I.M.; Nile, A.H.; Spagnuolo, P.A.; Jitkova, Y.; Gronda, M.; $\mathrm{Wu}, \mathrm{Y}$; Kim, M.K.; et al. Mapping the cellular response to small molecules using chemogenomic fitness signatures. Science 2014, 344, 208-211. [CrossRef] [PubMed]

65. Norris, M.; Lovell, S.; Delneri, D. Characterization and prediction of haploinsufficiency using systems-level gene properties in yeast. G3 (Bethesda) 2013, 3, 1965-1977. [CrossRef] [PubMed]

66. Parsons, A.B.; Brost, R.L.; Ding, H.; Li, Z.; Zhang, C.; Sheikh, B.; Brown, G.W.; Kane, P.M.; Hughes, T.R.; Boone, C. Integration of chemical-genetic and genetic interaction data links bioactive compounds to cellular target pathways. Nat. Biotechnol. 2004, 22, 62-69. [CrossRef] [PubMed]

67. Kim, J.H.; Campbell, B.C.; Yu, J.; Mahoney, N.; Chan, K.L.; Molyneux, R.J.; Bhatnagar, D.; Cleveland, T.E. Examination of fungal stress response genes using Saccharomyces cerevisiae as a model system: Targeting genes affecting aflatoxin biosynthesis by Aspergillus flavus Link. Appl. Microbiol. Biotechnol. 2005, 67, 807-815. [CrossRef] [PubMed]

68. Kim, J.H.; Hart-Cooper, W.; Chan, K.L.; Cheng, L.W.; Orts, W.J.; Johnson, K. Antifungal efficacy of octylgallate and 4-isopropyl-3-methylphenol for control of Aspergillus. Microbiol. Discov. 2016, 4, 2. [CrossRef]

69. Kim, J.H.; Mahoney, N.; Chan, K.L.; Campbell, B.C.; Haff, R.P.; Stanker, L.H. Use of benzo analogs to enhance antimycotic activity of kresoxim methyl for control of aflatoxigenic fungal pathogens. Front. Microbiol. 2014, 5, 87. [CrossRef]

70. Kim, J.H.; Chan, K.L.; Mahoney, N. Augmenting the activity of monoterpenoid phenols against fungal pathogens using 2-hydroxy-4-methoxybenzaldehyde that target cell wall integrity. Int. J. Mol. Sci. 2015, 16, 26850-26870. [CrossRef]

71. Clinical and Laboratory Standards Institute (CLSI). Reference Method for Broth Dilution Antifungal Susceptibility Testing of Filamentous Fungi: Approved Standard-Second Edition; CLSI document M38-A2; Clinical and Laboratory Standards Institute: Wayne, PA, USA, 2008; Volume 28.

72. Arendrup, M.C.; Cuenca-Estrella, M.; Lass-Flörl, C.; Hope, W. EUCAST technical note on the EUCAST definitive document EDef 7.2: Method for the determination of broth dilution minimum inhibitory concentrations of antifungal agents for yeasts EDef 7.2 (EUCAST-AFST). Clin. Microbiol. Infect. 2012, 18, E246-E247. [CrossRef]

73. Niimi, K.; Harding, D.R.; Parshot, R.; King, A.; Lun, D.J.; Decottignies, A.; Niimi, M.; Lin, S.; Cannon, R.D.; Goffeau, A.; et al. Chemosensitization of fluconazole resistance in Saccharomyces cerevisiae and pathogenic fungi by a D-octapeptide derivative. Antimicrob. Agents Chemother. 2004, 48, 1256-1271. [CrossRef]

74. Batova, M.; Klobucnikova, V.; Oblasova, Z.; Gregan, J.; Zahradnik, P.; Hapala, I.; Subik, J.; Schuller, C. Chemogenomic and transcriptome analysis identifies mode of action of the chemosensitizing agent CTBT (7-chlorotetrazolo[5,1-c]benzo[1,2,4]triazine). BMC Genom. 2010, 11, 153. [CrossRef]

75. Shirazi, F.; Kontoyiannis, D.P. Mitochondrial respiratory pathways inhibition in Rhizopus oryzae potentiates activity of posaconazole and itraconazole via apoptosis. PLoS ONE 2013, 8, e63393. [CrossRef] [PubMed]

76. Kim, J.H.; Mahoney, N.; Chan, K.L.; Molyneux, R.J.; May, G.S.; Campbell, B.C. Chemosensitization of fungal pathogens to antimicrobial agents using benzo analogs. FEMS Microbiol. Lett. 2008, 281, 64-72. [CrossRef] [PubMed]

77. Kojima, K.; Takano, Y.; Yoshimi, A.; Tanaka, C.; Kikuchi, T.; Okuno, T. Fungicide activity through activation of a fungal signalling pathway. Mol. Microbiol. 2004, 53, 1785-1796. [CrossRef] [PubMed]

78. Levin, D.E. Cell wall integrity signaling in Saccharomyces cerevisiae. Microbiol. Mol. Biol. Rev. 2005, 69, 262-291. [CrossRef]

79. Schwartz, M.A.; Madhani, H.D. Principles of MAP kinase signaling specificity in Saccharomyces cerevisiae. Annu. Rev. Genet. 2004, 38, 725-748. [CrossRef]

80. DrugCentral. Available online: http://drugcentral.org (accessed on 7 April 2019).

81. Aggregate Analysis of ClinicalTrials.gov (AACT). Available online: https://aact.ctti-clinicaltrials.org/(accessed on 7 April 2019).

(C) 2019 by the authors. Licensee MDPI, Basel, Switzerland. This article is an open access article distributed under the terms and conditions of the Creative Commons Attribution (CC BY) license (http://creativecommons.org/licenses/by/4.0/). 